\title{
The use of synthetic materials in the treatment of stress urinary incontinence
}

\author{
Robert Stanek ${ }^{1}$, Przemysław Kądziołka ${ }^{1}$, Anna M. Stanek², Krzysztof Szymanowski ${ }^{1}$, Maciej Wilczak ${ }^{2}$ \\ ${ }^{1}$ Department of Maternal and Child Health, Poznan University of Medical Sciences, Poznan, Poland \\ ${ }^{2}$ Chair and Department of Medical Education, Poznan University of Medical Sciences, Poznan, Poland
}

\begin{abstract}
Stress urinary incontinence is a very serious problem which has been noticed by the WHO. This difficult medical condition poses a serious problem as it affects c.a. $20 \%$ of the female population and it increases up to $35 \%$ in the group of females over 60 years of age. Since there is no single standard surgical procedure which could solve this problem, numerous synthetic materials are used for the operations. It seems that the materials are effective as they improve the condition of women suffering from stress urinary incontinence. Unfortunately these materials have their shortcomings which might lead to certain post-operative complications. Stress urinary incontinence is a disease which affects the social life of the patients. It has a high percentage of recurrence and causes the patient substantial difficulties with keeping high standards of personal hygiene which is consequence makes it impossible to fulfill their social roles. The etiology of this disease is complex and calls for a cross-disciplinary approach to the problem. As there are no standardized or unanimous treatment methods of stress urinary incontinence, numerous sources based on the clinical experience of many medical centers suggest performing TVT and TOT procedures as the most effective treatment methods. The efficacy of the TOT procedure is about $90.8 \%$.
\end{abstract}

Key words: urinary incontinence, urinary incontinence treatment.

\section{Introduction}

Stress urinary incontinence is a common health problem which substantially deteriorates the quality of life both private and social. It is defined as the loss of small amounts of urine associated with coughing, laughing, sneezing, sexual intercourse or prolonged standing. This difficult medical condition poses a serious problem as it affects c.a. $20 \%$ of the female population and it increases up to $35 \%$ in the group of females over 60 years of age [1].

Stress urinary incontinence is diagnosed with 0.5 $20 \%$ of nulliparae. $15-60 \%$ of multiparae are affected by this condition out of which $15 \%$ are women of 20 to 30 years of age, $22 \%$ of women aged $30-40,37 \%$ of women aged $40-50$ and $49 \%$ of women aged $50-60$ and as much as $60 \%$ of women in the age group of 60-70 [2].

During the lifetime of an average female, the risk of undergoing an operation due to pelvic organ prolapse and/or urinary incontinence amounts to $11 \%$ [3].

Stress incontinence risk factors include some obstetric episodes such as the number of childbirths, childbirth surgeries, the weight of a newborn exceeding $4000 \mathrm{~g}$, asthma, chronic obstructive pulmonary disease (COPD), obesity, old age of the patients as well as surgical operations carried out within the small pelvis [4].
According to the literature of the subject, there are several concepts which might explain the mechanism of stress incontinence. One of them describes this condition as a consequence of uneven transmission of abdominal pressure acting on the bladder and the urethra. Both the proximal urethra and the bladder neck are physiologically positioned high in the retropubic space, therefore the growing intra-abdominal tension is transferred in the same manner to the bladder as well as to the urethra. However, when the pelvic floor becomes weak and inadequately fulfils its functions, then a retroactive rotary movement occurs and the bladder and the urethra are moved downwards as well. As a result, the inter-abdominal hypertension is transferred more to the urethra than to the bladder, which in consequence leads to stress incontinence [5].

On the other hand, according to an alternative theory, stress urinary incontinence is caused by widening and shortening of the urethra or an uneven mobility of the anterior and posterior walls of the bladder and the proximal urethra which results from strain. This may press the urethra to the muscular layer and the fasciae which support the bladder [5].

Another hypothesis, known as "integral theory", is based on the fact that both stress urinary incontinence 
and urge incontinence have the same origin. Lowering of the anterior wall of the vaginal activates receptors which are susceptible to stretching within the neck of the bladder as well as in the proximal urethra which causes the reflex of emiction, which might cause hyperactivity of the detrusor. There are three independent, yet co-operating mechanisms which are responsible for the physiological anatomy of the anterior vaginal wall. The pubococcygeus muscle controls the anterior vaginal wall and exerts pressure on the urethra. It also pulls the vaginal wall backwards and downwards thus closing the neck of the bladder. The muscles of the pelvic floor pull the structure upwards and close the neck of the bladder which happens voluntarily. The lack of firmness of the anterior wall of the vagina might be the cause of these mechanisms, which in consequence leads to stress urinary incontinence [5].

Numerous examples in the literature prove that a three-month therapy involving exercising the muscles of the pelvic floor can yield positive results. Thus, the efficacy of these exercises in treating urinary stress incontinence is estimated as $27-88.4 \%$ [6].

The research on electrostimulation as a method of treatment in stress urinary incontinence points to its efficacy of $15-90 \%[7,8]$.

The inadequacy of non-invasive treatment has led to the development of surgical methods of treating the stress urinary incontinence. Historically, these included:

- 1913 - Kelley plication,

- 1949 - Marchall, Marchetti, Krantz - retropubic urethropexy,

- 1952 - Mazurek - colposuspension of the urethra on strands of fascia,

- 1959 - Pereyra - needle colposuspension,

- 1961 - Burch - urethropexy on Cooper's ligaments,

- 1973 - Scott - artificial urethral sphincter,

- 1991 - Vancaille and Schuessler - laparoscopic colposuspension,

- 1995 - TVT [9].

The most common treatment methods of stress urinary incontinence currently involve surgical operations which might be classified as follows:

- Plastic surgery of the interior vaginal wall when the fascia is applied (the Kelly plication).

- The Marshall-Marchetti-Krantz procedure, the Burch procedure and their laparoscopic modifications, the needle colposuspension - the Pereyra procedure.

- Sling procedures when the patient's own tissues as well as xenogeneic and synthetic materials might be applied.

- Periurethral injections of the patient's own fatty tissue, Teflon, collagen and synthetic materials.

- Implanting artificial urinary sphincters [10, 11]. Selecting the best method of incontinence treatment poses a substantial difficulty. Numerous factors must be considered. These include the patient's body weight, her age, the number of childbirths and the type of complications related to these as well as the question of whether or not the patient is planning to have children. The method of treatment depends on the patient's general condition and any comorbidities she might suffer from. The patient's physical (sport) activity is also important.

The effectiveness of the selected type of treatment depends on accurate diagnostics which correctly determines the cause of incontinence and the possibly coexisting pathology within the genitals.

The more effective methods of treatment of this anomaly include the procedures where synthetic materials are used [12].

Surgical treatment of stress urinary incontinence has been used for almost a century. Plastic surgery of the anterior vaginal wall is one of the most popular procedures. It was carried out in the 1970s with high intensity and it has not been completely abandoned so far. The procedure has lost its popularity due to a relatively high rate of recurrence of the condition which proves that its long-term efficiency amounted to $67-82 \%[13,14]$.

In light of contemporary knowledge, the application of new taping methods is characterized by time efficiency of the procedure. The possibility to use local anesthesia makes it undoubtedly more beneficial for the patient [15].

The most frequently performed surgeries are the TVT procedure (tension free vaginal tape) or the TOT procedure (trans obturator tape) which is currently gaining more and more popularity. The TVT method involves positioning a mesh tape by means of the retropubic technique [16].

Due to its substantial therapeutic efficiency rated at $83-95 \%$, and the fact that it is relatively easy to carry out, the procedure achieved the status of gold standard [12].

A correctly performed TVT procedure involves performing a suburethral incision of the vagina, dissecting it at the length of c.a. $2 \mathrm{~cm}$, then performing a lateral dissection towards the lower edge of the pubic bone and running the needle along the central surface of the pubic symphysis towards the shoulder located on the same side. While positioning the mesh, the needle must be controlled by the finger [16]. In order to avoid scarring of the urinary tract it is recommended that a cystoscopy is performed during the procedure. For the sake of safety, modern TVT kits are equipped with a special rail used for separating the bladder from the site of injection [16].

Currently minimally invasive kits like TFS - tissue fixation system and TVT Secure are offered. These allow for placing the tape underneath the urethra without the need to perform any incision. The procedure is successful when the fixing of the endings in the tendinous arch of the pelvic fascia is effected correctly $[16,17]$.

The TOT is currently performed more often than TVT as it is a technically simpler solution and has fewer 
complications, i.e. damage to the urethra and the bladder [18].

In the TOT procedure, the suburethral surface of the vagina is incised, tunnels are dissected and the tape is inserted via the openings. In this procedure, the positioning of the tape is very important as it should be placed exactly underneath the central part of the urethra. A too distal or proximal position might not bring about the desired therapeutic effect to lead to overreactivity of the bladder. In order to carry out the taping procedure correctly, prior to the operation the length of the urethra must be measured by means of the USG and the vagina must be incised very exactly $[16,18]$.

Regardless of the fact that surgical procedures always run some risk of post-operative complications, majority of patients decide to undergo this procedure as they view it as a single effective treatment in contrast to a long-term and possibly ineffective conservative treatment methods [17].

\section{Materials}

The effectiveness of the procedures using the patient's own tissues or synthetic tapes amounts to 80$90 \%$ [13].

The suburethral tapes are made of numerous types of material as well as of the patient's own tissues, allogenic materials prepared form cadavers, porcine skin tissue implants as well as these made of synthetic materials [11]. A typical patient's own material used for urethra suspension is a fascia of the rectus abdominus muscle or the fascia lata. In Poland, as in the countries of Western Europe, the materials made of porcine tissue have gained little popularity (Pelwicol, CR Bard). Most clinicians have been using synthetic materials in their practice. Modern implant materials are becoming more and more popular. These include woven materials, monofilament materials and micropore multifilament tapes. They may be made of Polytetrafluoroethylene (Gore-Tex), polyesters (Dacron) or silicone [19, 20].

One of the first tapes used in the procedure of urethra suspension was Mersilene tape (Ethicon, Edinburgh, UK). The material, in a form of a narrow band, has been used since 1962 . The use of polyethylene was abandoned, however, due to a high percentage of urethral obstruction or, in extreme cases, damage to the urethra [10]. In 1968, Moir described the use of a broader mesh loosely positioned underneath the floor of the urinary bladder and the urethra. The procedure had a low incidence of complications which included suburethral obstructions. The percentage of success was $78 \%$ [21].

A polypropylene mesh was first used by Morgan in 1970 . The technique is very similar to the currently used ones as the modification involved a different site of anchorage. In the Morgan method, a wide mesh was placed underneath the bladder neck and the urethra to be eventually anchored to Cooper's ligaments. Currently the mesh is anchored to the aponeurosis [21].

Gore-Tex (a derivative of Polytetrafluoroethylene) (WL Gore Inc., Flagstaff, Arizona, USA) was introduced as a synthetic material used for suburethral procedures as it is well tolerated by the organism and neutral to human tissues. It is also widely applied in vascular surgery where it is used as prosthesis material. The use of Gore-Tex almost immediately proved to be effective. Despite the fact that it is so commonly applied, especially in the US, it might be related to a high percentage of erosion and implant infections [21].

Nowadays some disposable polypropylene, monofilament tapes with large pores (above $75 \mu \mathrm{m}$ ) are used as standard materials in the procedures under discussion.

\section{Complications}

The complications of procedures where tension free suburethral tapes are used include punctures of the urinary bladder and post-mictional residue. It is estimated that the above complications occur in c.a. $10-15 \%$ patients. Other factors that cause complications include a damage to the intestine or a large blood vessel. All these are extremely serious as they may eventually be fatal [22].

The above data were obtained from a center which is very experienced in urogynecological surgery. However, the data were obtained as long as twelve years ago, which was before the techniques under discussion were introduced. At that time TVT was performed almost exclusively. Currently the percentage of damage to the urinary bladder, the urethra or micturition disorders is substantially lower, up to $1 \%$ [22].

The tapes inserted underneath the central part of the urethra are characterized by a low rate of complications and high therapeutic efficacy. Synthetic materials are readily available and, contrary to the natural ones, they do not call for additional procedures in which the material is obtained. The majority of synthetic materials, however, did not prove to be beneficial in operative treatment of incontinence as they eventually underwent defragmentation, shrinking or stretching, led to the formation of fistulas or the implant rejection. Moreover, they run a high risk of infection. Polypropylene proved to be one of the best materials as implants made of it are easily overgrown with connective tissue and they do not undergo infections. The mesh made of polypropylene must not come in contact with the bladder or the urethra as this might lead to an inflammatory process. The best result is obtained when the mesh is implanted in the intrafascial space without any tension and pressure exerted on the adjacent organs [23].

Within a year of the procedure, a mesh positioned evenly underneath the urethra may shrink up to 20- 
$30 \%$ after the implantation, whereas if it is wrongly positioned and folded, it may shrink up to $75 \%$ of its volume. The above mechanisms may lead to obstruction in the urine flow and consequently to the erosion of the urethra [23].

The mesh implanted directly underneath the urethra or the bladder may cause a local inflammation and penetration of the material into the bladder or the urethra. A frequent complication is narrowing of the urethra which obstructs the urination. The same mechanism may cause disorders in microcirculation, post-operative wound healing and erosion of the urethra or the vaginal mucosa.

Another complication caused by microcirculatory disorders and the inflammatory process is vaginal and clitoral anesthesia which might impair sexual activity [23].

One of the most frequent complications resulting from retropubic procedures is an overactive bladder syndrome caused by placing the implant underneath the bladder neck which affects up to $25 \%$ of the patients. This group includes mainly the patients diagnosed with mixed urinary incontinence [24].

Another important element that might influence the risk and the gravity of complications is any comorbidities that the patient may suffer from. Diabetes, and vascular disorders might increase the risk of such serious complications as sepsis, pneumonia, venous thromboembolism or myocardial infarction. Moreover, obesity of BMI $\geq 35$ $\mathrm{kg} / \mathrm{m}^{2}$ might increase the difficulty of the procedure as well as postoperative complications $[19,20]$.

A correctly carried out surgery has a vast impact on decreasing the probability of occurrence of complications, both erosion related and those impairing the activity of the urinary system. In the treatment of urogenital atrophy, the success of operation depends on premedication as well as the professional execution of all the manual operations. Incorrect preparation of the patient might cause non-physiological healing of the postoperative wound caused by hyperestrogenism which destroys the final result of even best performed surgery [25].

\section{Summary}

Stress urinary incontinence is a disease which affects the social life of patients. It has a high percentage of recurrence and causes substantial difficulties for the patient with keeping high standards of personal hygiene, which in consequence makes it impossible to fulfill their social roles. The etiology of this disease is complex and calls for a cross-disciplinary approach to the problem [10].

Based on the experience of various medical centers, the lack of satisfactory efficacy of non-invasive methods of treating stress urinary incontinence as well as a poor efficacy of surgical methods implemented be- fore the age of modern prosthetic materials have contributed to an increased popularity of TVT (tension free vaginal tape) and TOT (trans obturator tape) procedures as the most effective treatment methods. Rechberger assesses the efficacy of the TOT as $90.8 \%$ [10].

Also Per Johnson is in favor of the above surgical procedures as he believes the method is safe and efficient. The surgery can be carried out as an outpatient procedure under local anesthesia which limits the time of recovery to one day [26].

A cross-disciplinary approach to this issue allows for the use of new technologies. The materials used in the majority of operations are safe synthetic meshes which are absorbable and partially absorbable. It has recently been reported that collagen implants are not only as good as the synthetic meshes, but also they are devoid of certain flaws, i.e. they pose a lesser risk of erosion. This might be confirmed by a $93 \%$ efficacy of the procedures in which porcine skin collagen was used (Pelvicol). The lack of long-term follow-up must, however, postpone the enthusiasm evoked by such encouraging results [12].

Regretfully, there is no material that is free from any shortcomings whatsoever. It is clear though what characteristics such a perfect material should have. These include:

- full compatibility,

- the ability to cause only a negligible allergic and inflammatory reaction,

- stable long-term biomechanical properties,

- ease of sterilization,

- insusceptibility to bacterial infections,

- ease of use,

- cost efficiency [25].

The above description of "perfect" prosthetic materials shows that there still is much to be developed in the area.

\section{Disclosure}

Authors report no conflict of interest.

\section{References}

1. Surcel C, Savu C, Chibelean C, et al. Comparative analysis of different surgical procedures for female stress urinary incontinence. Is stem cell implantation the future? Rom J Morphol Embryol 2012; 53: 151-154.

2. Prather H, Spitznagle TM, Dugan SA. Recognizing and treating pelvic pain and pelvic floor dysfunction. Phys Med Rehabil Clin N Am 2007; 18: 477-496.

3. Olsen A, Smith V, Bergstrom J, et al. Epidemiology of surgically managed pelvic organ prolapse and urinary incontinance. Obstet Gynecol 1997; 89: 501-506.

4. Chmielewska DD, Piecha M, Kwaśna K, et al. Nietrzymanie moczu problem współczesnej kobiety. Prz Menopauzalny 2013; 11: 378-384.

5. Blaivas J, Chancellor M, Weiss J, Verhaaren M. Atlas urodynamiki. Medipage, Warszawa 2008; 184-185.

6. Kulikowski M, Mirończuk J, Młodzianowska K. Rehabilitacja mięśni dna miednicy $u$ kobiet $z$ wysiłkowym nietrzymaniem moczu. In: 
Zaburzenia statyki narządu rodnego wysiłkowe nietrzymanie moczu niedowartościowany problem kliniczny. Praca zbiorowa. Gomuła A (ed.). Medan, Białystok 1999; 287-291. [Rehabilitation of pelvic floor muscles with female patients suffering from stress urinary incontinence - Pelvic organ prolapse, stress urinary incontinence - an underestimated clinical problem, the proceedings to the Symposium of Operational Gynecology Section of Polish Gynecological Society in Białystok, 25-27 November 1999. Gomuła A (ed.). Medan Publishing House, Białystok 1999; 287291.

7. Gałczyński K, Romanek K, Kulik-Rechberger B, Rechberger T. Elektrostymulacja mięśni dna miednicy w leczeniu nietrzymania moczu u kobiet. Prz Menopauzalny 2011; 6: 427-431.

8. Wlaźlak E, Surkont G, Suzin J. Pessaroterapia w nowoczesnej uroginekologii. Przegl Urol 2010; 6 (64).

9. Leśniczak B, Szymańska I, Krasomski G. Ginekologia Praktyczna 2010; 2: 23-26.

10. Rogoszewski M, Grodoń M, Skrobarczyk J, et al. Wyniki leczenia operacyjnego kobiet chorych na wysitkowe nietrzymanie moczu. Urol Pol 2007; 60 .

11. Trzepizur Z, Miękoś E. Ocena porównawcza metod operacyjnego leczenia wysitkowego nietrzymania moczu u kobiet. Zaburzenia statyki narządu rodnego. In: Wysitkowe nietrzymanie moczu - niedowartościowany problem kliniczny. Gomuła A (ed.). Materiały Sympozjum Naukowego Sekcji Ginekologii Operacyjnej Polskiego Towarzystwa Ginekologicznego, Białystok, 25-27 listopada 1999; 221-234.

12. Szymański J, Siekierski PB, Baranowski W. Skuteczność leczenia wysitkowego nietrzymania moczu metodą załonową i przezzasłonową - obserwacja średnioterminowa. Prz Menopauzalny 2008; 5: 248-255.

13. Operacyjne leczenie urodynamicznego wysiłkowego nietrzymania moczu. Aktualne (2003 r.). Wytyczne Royal College of Obstetricians and Gynaecologists. Medycyna Praktyczna 2004; 3: 31-46.

14. Zajda J. Bulking - moda czy metoda? Przegl Urol 2012; 2: 16-18.

15. Baranowski W, Rogowski A, Doniec J, Włodzisławska A. Surgical treatment of female stress urinary incontinence with the Gynecare TVT Secur $^{\mathrm{TM}}$ System - preliminary report. Prz Menopauzalny 2010; 1: 13-16.

16. Rechberger $T$ (ed.). Nietrzymanie moczu i zaburzenia statyki dna miednicy u kobiet. Termedia, Poznań 2009; 221-225.

17. Rechberger T. Leczenie operacyjne nietrzymania moczu u kobiet - aktualne trendy. Przegl Urol 2007; 1: 51-54.

18. Mellier G, Benayed B, Bretones S, Pasquiera JC. Suburethral tape via the obturator route: is the TOT a simplification of the TVT? Int Urogynecol J Pelvic Floor Dysfunct 2004; 15: 227-232.

19. Costantini E, Lazzeri M, Porena M. Managing complications after midurethral sling for stress urinary incontinence. EAU-EBU Update Series 2007; 5: 232-240.

20. Dybowski B. Powikłania operacji wysitkowego nietrzymania moczu z użyciem taśmy. Przegl Urol 2009; 2: 46-48.

21. Bidmead J, Cardozo L. Sling techniques in the treatment of genuine stress incontinence. BJOG 2000; 107: 147-156.

22. Surkont G, Wlaźlak E, Suzin J. Nietrzymanie moczu u kobiet - problem społeczny, medyczny i naukowy. Prz Menopauzalny 2003; 1: 59-65.

23. Trabucco AF, Witkowski P. Nowa beznapięciowa taśma w leczeniu wysitkowego nietrzymania moczu. In: Nowe trendy w uroginekologii. Rechberger T (ed.). Akademia Medyczna w Lublinie, Lublin 2005; 308322.

24. Cendrowski K. Powikłania po zabiegach korekcji zaburzonej statyki narządów płciowych i operacjach nietrzymania moczu. In: Powikłania pooperacyjne w ginekologii. Śpiewankiewicz B (ed.). Wyd. Lek. PZWL, Warszawa 2009; 179-188.

25. Rechberger T, Bartuzi A, Perżyło K. Zaburzenia statyki narządu rodnego przyczyny, diagnostyka, symptomatologia i leczenie. Prz Menopauzalny 2011; 3: 206-217.

26. Ulmsten $U$, Johnson P, Rezapour M. A three-year follow up of tension free vaginal tape for surgical treatment of female stress urinary incontinence. Br J Obstet Gynaecol 1999; 106: 345-350. 